\title{
Art as an Antidote to Clandestine Migration: a study of Chimamanda Ngozi Adichie's Americanah and NoViolet Bulawayo's We Need New Names
}

\author{
Alphonse Dorien Makosso* \\ Enseignant chercheur, Maitre-Assistant à L'Ecole Normale Supérieure Université Marien Ngouabi Republic of \\ the Congo
}

*Corresponding Author: Alphonse Dorien Makosso, Enseignant chercheur, Maitre-Assistant à L'Ecole Normale Supérieure Université Marien Ngouabi Republic of the Congo

\begin{abstract}
Migration is one of the topical issues which is increasingly gaining critical protracted interest among writers, critics and linguistic scholars in the world in this era of globalization with the influx of people across borders. The major focus in this work is to examine how migrant literature's two acclaimed female writers of third generation, the Nigerian Chimamanda Ngozi Adichie and the Zimbabwean No Violet Bulawayo use art as an effective means of representing social reality, if not instrumental in understanding and interpreting aspects of clandestine migration, its inherent dialectics. It draws from the pragmatic functionality of literature as springing from creative consciousness, that to say on the theory of realism which has a great concern for the effect of the action upon the character and a tendency to explore the psychology of the actors in their stories. As a final assessment, these magnum opuses, Americanah and We Need New Names, rank among the recent literary texts focusing on the social contexts in the migrants' country of origin which prompt young Africans to leave, on the experience of migration itself, on the mixed reception which they may receive in Western 'Eldorado', on experiences of racism and hostility, and on the sense of rootlessness and the search for identity which finally leads a mere disenchantment.
\end{abstract}

Keywords: Migrant literature - pragmatic functionality - disenchantment - societal dialectics migrants' countries -search for identity.

\section{INTRODUCTION}

Migration has become a reality that has been recently revived and is increasingly gaining critical protracted interest in the realm of the twenty-first century literature. Migration literature is considered as a new world literature. Elien, Declercq who coins this term of "migrant literature" in 2011 in his seminal work "Écrituremigrante', 'littérature (im)migrante', 'migration literature': réflexionssur un concept aux contours imprécis". This neologism "migrant literature", though new literary trend, but has quickly undergone sizeable conceptual mutations, going from Exile to migrant literature, from migration literature to migrant writing (Ecrituremigrante). Rather, the term 'inter-national literature' is even preferred by other scholars.(www.wikipedia.com, 10/05/2021) In the same connection, and in reference to the ideas put forward by his predecessor, the German Scholar Katie, Petersen gives a clear definition of this neologism:

Migrant literature often focuses on the social contexts in the migrants' country of origin which prompt them to leave, on the experience of migration itself, on the mixed reception which they may receive in the country of arrival, on experiences of racism and hostility, and on the sense of rootlessness and the search for identity which can result from displacement and cultural diversity. (www.yorku.ca.29/06/2021)

In the context of African literature, migration has become a very important field of investigation since the beginning of the twenty-first century. Many works by African female writers of the third generation such as Buchi Emecheta's Second-Class Citizen (1974), Chika Unigwe's On Black Sisters' Street (2009), Chimamanda Ngozi Adichie's Purple Hibiscus (2004), Half of a Yellow Sun (2006) and Americanah (2013), Leila Aboulela's Elsewhere, Home (2018), and NoViolet Bulawayo's We Need New Names (2013) just to mention some, areamong the prominent texts dominated by migration narratives. 
The major focus in this work is to examine how migrant literature's two acclaimed female writers of third generation, the Nigerian Chimamanda Ngozi Adichie and the Zimbabwean NoViolet Bulawayo use art as an effective means of representing social reality, if not instrumental in understanding and interpreting aspects of the illusion of migration with all its inherent dialectics.

The hypothesis backing up this study is thatAfrica keeps on losing its brave youths who, for various reasons, crave for overseas and finally, decide to flee their homelandin endless bands, at their life's peril, leaving behind an empty and devastated continent, as NoViolet Bulawayo (2014:145)warns:

Look at them leaving in droves, the children of the land, just look at them leaving in droves. Those with nothing are crossing borders. Those with strength are crossing borders. Those with ambitions are crossing borders. Those with hopes are crossing borders. Those with loss are crossing borders. Those in pain are crossing borders. Moving, running, emigrating, going, deserting, walking, quitting, flying, fleeing - ton all over, to countries near and far, to countries whose names they cannot pronounce. They are leaving in droves.

The disaster which comes with the migration of African youths is epitomized through the action verbs such as 'Moving, running, emigrating, going, deserting, walking, quitting, flying, fleeing'. Thus, this study has been prompted byits topically and relevance around the world in general, and in Africa South of the Sahara in particular. As the matter of fact, a quick glimpse at headlines of written and online Media reveals how many people, from all ages, in the Northern Africa for example, are everyday taking risk to embark on the gloomy path of the clandestine and illegal immigration in spite of the danger it represents for their lives.

The choice of Americanah and We Need New Names as templates for this study lies on this premise. For, these two literary texts discuss the multifaceted and intertwined combination of experiences that afflict and characterize transnational trajectory and the complex dynamics of diaspora existence. The gist of this study is then to show how Chimamanda Ngozi's and Bulawayo's transnational engagement underscores the perception of the West as an 'el Dorado' of sorts.

This study draws from the pragmatic functionality of literature as springing from creative consciousness, that to say on the theory of realism which has a great concern for the effect of the action upon the character and a tendency to explore the psychology of the actors in their stories.(Holman1980:366). Accordingly, Kofi Agyekum (2013: 208) asserts:

Realism is the theory in art and literature where works are associated to real life situations and accurate representation of man, nature and environment. [...] Realism therefore looks at things from a pragmatic point of view. Realists, are thus believers in pragmatism and seek to find the relative truth of things based on pragmatic context and verifiable and probable experiences and evidence.

From this pragmatic framework, this paper argues then that Africans are challenged by the instability arising from the quest for survival in the New World as a result of imperialism. Hitherto, the Nigerian and Zimbabwean immigrants in the novels under consideration are depicted as grappling with difficulties and identity crisis.

Generally referred to as the act or the process of moving from one region or country to another, 'Migrancy' is as old as the world, and is from times immemorial, induced by several reasons. It is a critically shared view that for African 'migration literature' writers the lack of economic opportunity, poverty, conflicts, collapsed educational system and bad government/corruption rack are among the main factors causing the youths to flee from 'hell' of Africa and migrate.

According to Carmen Concilio, in her article entitled "Paradigms of Migration: The Fight and the Fall", the deportation of the African's population is caused by many reasons but most of the commons are: Social conditions, Education and Dictatorship. In "Return Migration: Theory and Empirical Evidence from the UK" (2007:237), Dustmann and Weisson their part, expose the psychological trauma of transnational subjects and opine that economic motives for migration and natural disaster or persecution are the main reasons why individuals migrate.

Chimamanda Ngozi Adichie's Americanah and NoViolet Bulawayo's We Need New Names buttress the fact African youths' migration is attributed to political instability, conflicts and violence plaguing 
most of countries in Africa. Analyzing aspects of Migration in Adichie's works, the Burkinabe AndréKabore explores the cultural and social complexities of the immigrants' country of origin and the host lands. Accordingly, he (2016:16) concludes that "Adichie, like other contemporary Nigerian novelists is capturing the current spate of human trafficking, prostitution, illegal and irregular migration in her works.'Writing for the 'New York Times', Mike Peed (online, consulted April 2021) asserts that "Americanah is witheringly trenchant and hugely empathetic, both worldly and geographically precise, a novel that holds the discomfiting realities of our times fearlessly before us. It never feels false." Similarly, critics raisedfrom everywhere, praising Bulawayo's We Need New Names as an African migrant novel. For DavidSmith (September 4, 2013), "NoViolet Bulawayo tells of heartbreak of homecoming in Mugabe's Zimbabwe".In the same wave, The Daily Mailmagazine reviews We Need New Names as "Bulawayo's emotionally articulate novel turns a familiar tale of immigrant displacement into a heroic ballad. Bulawayo's courage and her literary scope shine out from this outstanding debut."As for JasonSteger (2014)quoted in The Independent On Sunday, We Need New Namesis an outcry from home, "a brilliantly poignant tale of what it is to be an outsider in a strange land", for:

How does a writer tell the story of a traumatised nation without being unremittingly bleak? NoViolet Bulawayo manages it by forming a cast of characters so delightful and joyous that the reader is seduced by their antics at the same time as finding out about the country's troubles...A debut that is poignant and moving but which also grows with humanity and humour.

Three main points are considered in the completion of this study. For the sake illustrating how both migrant literature's female writers, use Art as an antidote to the illusion of migration, it is worth focusing on African youth's longing for transnational spaces prior considering the authoresses' criticism of migration as ideological weapon to dissuade prospective candidates for a seemingly hopeful but dramatic adventure to the West. Finally, a clear motion will be make on Adichie's and Bulawayo's unequivocal ideological contribution to the burning issue of illegal migration and its subsequent drawbacks.

\section{African Youths' Craving For Transnational SpaCeS}

There are various inducing immigrants to migrate to another country. Most of the time, and mainly in the African context, migration is attributed to conflict, human rights violations, political discrepancy, poor education system, unemployment, and poverty. However, it is also a critically shared view that many African Youth's migration is induced just by their craving for overseas. They choose to migrate in order to gain access to opportunities and services in the host countries.

In Americanah, for instance, the roaming to America and Europe of Ifemelu and Obinze, two characters from a Nigerian poor Background is born out of the collapse in the Nigerian educational system. Their migration is induced by a failure of leadership which has made strikes in the Nigerian universities the norm rather than an exception: "Strikes now were common. In the newspapers, university lecturers listed their complaints. The agreements that were trampled in the dust by government men whose own children were schooling abroad." (p.98)These repetitive strikes dramatically affect the youths who have no alternative that resorting to violence, as the narrator keeps on depicting Ifemelu disenchantment with the Nigerian education system:

The strike lasted too long. The weeks crawled past. Ifemelu was restless, antsy; everyday she listened to the news, hoping to hear that the strike was over...Her mother asked if she wanted to join the sewing class at church, to keep her occupied, and her father said that this, the unending university strike, was why young people became armed robbers. The strike was nationwide, and all her friends were home... (Americanah, p. 91)

They are fed up with recurrent strikes, as the narrator reveals Ifemelu's worries in the following passage:

Campuses were emptied, classrooms drained of life, students hoped for short strikes, because they could not hope to have no strike at all. Everyone was talking about leaving. [...] students and teachers are craving to leave. When the strike ended, Ifemelu returned to Nsukka, eased back into campus life, and from time to time, she dreamed of America. (pp.98-99) 
Analysing Ifemelu's longing for America, Laura Pearson (online, consulted April 2021), writes:

Following graduation, the young, smitten pair head to university in Nsukka, but politics interfere: The lecturers go on strike for weeks, and the campus shuts down. Ifemelu is forced to wait out the strike back in Lagos. Meanwhile, her aunt, who lives in Brooklyn, urges her to move to the United States to continue her studies. Ifemelu imagines an enchanted American life" in a house from the Cosby Show,' in a school with students holding notebooks miraculously free of wear and crease.

Learners are not the only ones to complain about chaotic management of schools by the military regime, teachers too, struggle for their salary and better working conditions, as Ginika's father, one of teachers at university contends:

We are not sheep. This regime is treating us like sheep and we are starting to behave as if we are sheep. I have not been able to do any real research in years, because every day I am organizing strikes and talking about unpaid salary and there is no chalk in the classrooms. (Americanah, p. 65)

The situation is hardly shining in Zimbabwe as depicted in Bulawayo's We Need New Names, where the population is fed up recurrent strikes in social public services such as Health and education. As a matter of fact, when Darling's father, is brought to hospital, unfortunately, nobody is there to receive the patients because nurses or doctors, and other personals are on strike for working conditions and their unpaid salary, as the narrator asserts: "[...] there are no doctors or nurses at the hospital because they are always on strike [...]"(p.99).

Furthermore, teachers prefer deserting their country and go in new lands to land a hand. For this reason, Darling and her friends have their education seriously disrupted because their teachers left, as Mother of Bones regrets: "I don't go to school anymore because all the teachers left to teach over in South Africa and Botswana and Namibia and them, where there's better money." (p.30)

As it can be seen, learners and teachers both flee from their home countries just to gain access to opportunities and services in other countries or continent such as America and Europe promising a well-structured educational system in order to live a stable and fulfilling life. As students, they have been brought up to believe that "a university education means a good job or the key to better life.

Another immigrants' push factor is the lack of employment opportunities in the home countries. Since getting a valuable job corresponding to their university education becomes unrealistic, they have no alternative than to move. This is the case of the four female characters in On Black Sisters' Street, a novel by Chika Unigwe: Sissi and her co-migrants, Efe and Ama. Indeed, Sissi, a young Nigerian university graduate character, grabs the opportunity to travel to Belgium because she cannot afford finding a job in her home country. As for Efe and Ama, coming both from a poor background, they are also driven by similar motives. They are hooked by seemingly helpful agents to leave Nigeria for Europe to alleviate them from endemic poverty. If Efe is in search for financial support in order afford not only for her son whose father had rejected but for her siblings who depend on her (p.82), Ama has her thoughts on a new life, she needs making her own money so as to build her business (p.169)

Talking about poor living conditions as another reason that drives Africans to flee their home countries, some striking illustrations are provided in novels under consideration. In We Need New Names, the social malaise becomes too obvious that Darling and Bastard who embody the African vulnerable youths, have no other choice than absconding Paradise (Zimbabwe) for America with the hope of reaching a radiant life, as Bastard asserts:

When we grow up we'll stop stealing guavas and move on to bigger things inside the houses. I'm not really worried about that because when that time comes, I'll not even be here; I'll be living in America with Aunt Fostalina, eating real food and doing better things than stealing. But for now, the guavas.[...] I'm going to America to live in America with Aunt Fostalina, it won't be long, you'll see. [...]I'm going. [...] Well, I go to that America and work in nursing homes. (pp.10, 14, 15)

The phrases 'eating real food' and 'But for now, the guavas' epitomize the children' food starvation with "the guavas ripping their anuses". (p. 160) Indeed, in the shantytown called 'Paradise', their 
home place, the youth have no alternative but moving to Budapest and steal guavas which almost become the favorite diet, a very meager diet that Bastard satirizes:

Nobody says it, but I know we are constipated again, all of us, because nobody is trying to talk, or to get up and leave. We just eat a lot of guavas because it's the only way to kill our hunger, and when it comes to defecating, we get in so much pain it becomes an almost impossible task, like you are trying to give birth to a country. (p 16)

Hence, immigrating is not optional but a must for they don't imagine brilliant future in their own country, as they vehemently contend: "Nobody wants to be rags of countries like Congo, like Somalia, like Iraq, like Sudan, like Haiti, like Sri Lanka, and not even this one we live in. (...) Who wants to be a terrible place of hunger and things failing apart? ( $\mathrm{p} 49$ )Allusions to countries quoted here respond to a certain three-level classification of countries that comes out after the country-game. Accordingly, these countries, and especially Zimbabwe, her homeland, ranks among the poorest places in the world so that players are dissuaded to select them, as they keep on:

First we have to fight-over the names because everybody wants to be certain countries, like everybody wants to be the USA and Britain and Canada and Australia and Switzerland and France and Italy and Sweden and Germany and Russia and Greece and them. These are the country-countries. If you lose the fight, then you just have to settle for countries like Dubai and South Africa and Botswana and Tanzania and them. They are not country-countries, but at least life is better than here. (We Need New Names,p 49)

From this passage one surmises, why Darling's father leaves Paradise (Zimbabwe) for South Africa, though it does not rank among the 'county-countries', an option that his wife does not share, as Darling asserts:

Mother had not wanted Father to leave for South Africa to begin with, but it was at that time when everybody was going to South Africa and other countries, some near, some far, some very, very far. They were leaving, just leaving in droves, and Father wanted to leave with everybody and he was going to leave and nobody would stop him. (We Need New Names, p. 91)

Darling's father is not the only one to leave. Paradise which the microcosm of Africa keeps on losing its brave youths who, longing for 'fertile pasture grounds', decide to leave, as the narrator dramatizes:

Look at them leaving in droves, the children of the land, just look at them leaving in droves. Those with nothing are crossing borders. Those with strength are crossing borders. Those with ambitions are crossing borders. Those with hopes are crossing borders. Those with loss are crossing borders. Those in pain are crossing borders. Moving, running, emigrating, going, deserting, walking, quitting, flying, fleeing - ton all over, to countries near and far, to countries whose names they cannot pronounce. They are leaving in droves. (p. 145)

In effect, the disaster which comes with the migration of African youths is epitomized through the action verbs such as 'Moving, running, emigrating, going, deserting, walking, quitting, flying, fleeing'. However, the phrase 'Look at them leaving in droves' which comes like a refrain in the above passage, indicates that what the authoress regrets the most is the way African immigrants desert in endless bands, at their life's peril, leaving behind an empty and devastated continent, as she furthers:

Look at the children of the land leaving in droves, leaving their own land with bleeding wounds on their bodies and shock on their faces and blood in their hearts and hunger in their stomachs and grief in their footsteps. Leaving their mothers and fathers and children behind, leaving their umbilical cords underneath the soil, leaving the bones of their ancestors in the earth leaving everything that makes them who and what they are, leaving because it is no longer possible to stay. (p. 145)

Like her father, Darling herself longs for overseas, specifically America. While playing with her friends, she does not hide all the time her longing to travel and join her aunt in America, the 'countrycountry', meaning 'real country':

If I'm lucky, like today, I get to the U.S.A., which is a country-country; who doesn't know that the U.S.A. is the big baboon of the world? I feel like it's my country now because my 
aunt Fostalina lives there, in Destroyedmichygen. Once her things are in order she'll come and get me and I will go and live there also. (We Need New Names, p. 49)

It is also important to note that political imbalance, human rights violations, and all kinds of persecution plaguing most countries in Africaare among the factors of migration. In some cases, people have no other alternative than fleeing their homeland where they have dwelt for ages just because of oppressions.

Analysing Americanah as a literary reference to military upheavals that Nigeria had gone through, Maria Duckham (2016-2017: 4) writes: "Americanahis a novel that is embedded in the political and cultural heritage of Nigeria. Without this background, the story does not function as each of the characters' respective diaspora stems from political unrest." This political unrest due to the successive authoritative military regimes is, according to Duckham(Ibid., p.11), one of the factors of migration, if not the most prominent, as she furthers:

After the independence of 1960, several policies were put in place in order to develop a tertiary system which promoted the education for all. However, a succession of military authoritative regimes and economic upheavals made this development almost impossible. University staff went on strike for several months at a time. As a result, both groups looked to new horizons in order to secure better chances for their education and professional careers.

In Adichie's Americanah, Aunty Uju's migration to America is attributed to family imbalance, especially after the death of her boyfriend, the General. Hence, she imperatively flee Nigeria in order to flee attacks from her late boyfriend's family. Aunty Uju's distressful situation reminds Chika Unigwe's On Black Sisters' Street with regard to Alek whose migration stems from political upheavals. Indeed, she is induced to leave her homeland after the extermination of her family members by the Janjaweed paramilitaries in Sudan.

The situation is almost the same in Zimbabwe where the social crisis reaches a threatening pitch, mainly under the repressive rule of the former president Robert Mugabe, as BabacarDiakhate (2018: 39) writes:

In July 2005 when Robert Mugabe proceeded to a national operation called operation Murambatsvina or 'restoring order', which consisted in demolishing the derelict houses inhabited by the lower classes, pretexting to fight poverty. [...] Around 650,000 to 700,000 people lost either the basis of their livelihood or their homes, or both. Mugabe's plan to 'restore order' was to bulldoze communities with no warning and to push those to live in rural areas of Zimbabwe.

In We Need New Names, NoViolet Bulawayo fictionalizes this chaotic period resulting from Mugabe's mismanagement of power with regard to Darling's family which moves to Paradise after the bulldozing of their house by the militia during the "Murambatsvina operation". A distressful life sequence that the heroine still remembers, as it always haunts her nights and even prevents her to sleep:

Now I am counting inside my head; this way I will not sleep. Nobody knows that sometimes I do not sleep, I am the hare. Even if I want to sleep I cannot because if I sleep the dream will come, and I don't want it to come. I am afraid of bulldozers and those men and police, afraid that if I let the dream come, they will get out of it and become real. I dream about what happened back at our house before we came to Paradise. I try to push it away and push it away but the dream keeps coming and coming like bees, like rain like graves at Heavenway. In my dream, which is not a dream-dream because it is also truth that happened, the bulldozers appear boiling. (We Need New Names, pp.64-65)

Through Darling's dream, "which is not a dream-dream because it is also truth that happened", the authoress shows the extent to which victims of violence bear psychological trauma for the rest of their lifetime. Sentences such as "Even if I want to sleep I cannot because if I sleep the dream will come, and I don't want it to come" and "I try to push it away and push it away but the dream keeps coming and coming like bees, like rain like graves at Heavenway" evidence Darling's paranoia. For, what she can help understand is the mischievousness with which their house has been bulldozed by the by the militia, as she bitterly furthers: 
The men driving the bulldozers are laughing. I hear the adults saying, Why whywhy, what have we done, what have we done, what have we done? Then the lorries come carrying the police with those guns and baton sticks and we run and hide inside the houses, but it's no use hiding because the bulldozers start bulldozing and bulldozing and we are screaming and screaming. The fathers are throwing hands in the air like women and saying angry things and kicking stones. The women are screaming the names of the children to see where we are and they are grabbing things from the houses: plates, clothes, a Bible, food, just grabbing whatever they can grab. And there is dust all over from the crumbling walls; it gets into our hair and mouths and noses and makes us cough and cough. (p.65)

Here, sentences such as 'The men driving the bulldozers are laughing' and 'bulldozers start bulldozing and bulldozing and we are screaming and screaming' or 'they are grabbing things from the houses: plates, clothes, a Bible, food, just grabbing whatever they can grab' dramatize the leaders' sadism and the people's distress. Indeed, in reaction to the inattentiveness and wickedness of their leaders, the vulnerable people are induced to seek refuge wherever they can, and start a new piteous living, almost with nothing but a few things that they grab from their crawling houses.

To conclude this point, one can assert that in Americanah and We Need New Names, characters' diaspora stems from antidemocratic practices such as ill-treatments, arrests and assassinations, and repeated strikes and other intricacies. Due to the messiness of things because of the mismanagement of powerin their country, people realize that it is no longer possible to stay. They chose to flee in the search for prosperous grounds where they can lead a normal 'human' life, and hope for a better future. A propensity to migration that both Adichie and Bulawayo criticize for they opine that sometimes the new destination is not an Eldorado but a mirage.

\section{Psychological Trauma Of Transnational Subjects}

Immigrant characters who longed for the Transnational spaces chiefly Western countries as lands filled with milk and honey, where every dream and aspiration would be fulfilled, are grossly disillusioned and frustrated at the belated realization. The novels under consideration expose the psychological trauma of the transnational subjects as the authoresses give a dramatic picture of a few characters challenging harsh living conditions in the host countries. For in a bid to integrate, immigrants are forced to adapt; alienating themselves and their identities, extremely fragmented. These imponderables, or "the disruptive effects of mobility" (P. Jay, 2010: 155) that reduce them into 'infra-humanity' predominantly rang from racism, the difficulty to adapt themselves to the new society the resort to menial jobs, sham practices, and homesickness.

Generally referred to as an animosity or prejudice against people who belong to other races, 'Racism' implies a belief in a certain racial superiority. Racists think and even maintain that people of different races have different qualities and abilities, and that some races are inherently superior or inferior. In the framework of this study, racial discrimination is a burning issues with regard to the unfair treatment that Black immigrants are often victims of in the host lands. A phenomenon that both authoresses bitterly experienced themselves as immigrants.

In an interview with Damian Woetzel (2014), Chimamanda Ngozi Adichie remembers of racism in America in the following terms: "It didn't take me very long to realize that in America black was not necessarily a good thing, and that black came with many negative assumptions. And so I didn't want to be black. I'm not black. I'm Nigerian. I'm Igbo. Race was not an identity I was willing to take." In effect, when she joined Uche, her sister, in the United States, Adichie realised that she was black. Back in Nigeria, she did not think of herself as being black, but as soon as she arrived in America for college, Adichie began to be identified by the colour of her skin. In Brooklyn for example, an African-American called her 'sister' and she did not appreciate it because 'sister' meant 'blackness', a term carrying a pejorative connotation. A very distrustful reality the prejudice of which she still bear in her innermost, as she recently confesses it in an interview with Cl. Juompan-Yakan (2020):

America is a mix of things. I went there thinking it was this perfect place because I'd watched films and when I got there the reality was different. There is a lot of poverty, a lot of racism, and I discovered a new identity as a black person. It took me making the choice to go and educate myself about what African-Americans have gone through for me to identity as black. So now I'm very politically black in America in a way that I wasn't before, because I had to learn it. 
As for Bulawayo, once she left Zimbabwe for the United States, she is grossly frustrated to discover that the host communities, moved by racial considerations, sometimesinfringe the Blacks' human rights. In an interview with Sabine Peschel (2015), the Zimbabwean novelist lends credence to this fact, for having, herself experienced such privations as an immigrant in America:

Whenever somebody crosses geographical spaces, whenever we cross cultures, something is lost. I remember just from my own experience that I spent the first year in the US in silence. I moved from being one of the noisiest kids in class to being the quietest. And I was dealing with all kinds of things, especially culture shock and failure to access the language. So that is exactly what is happening to Darling. Part of her identity is tied to space. So without her language and without the specific group of people she interacts with, she has to become a different person.

Consequently, these racial discriminations are woven into Adichie's and Bulawayo's fictional works. In Americanah, for instance, when Ifemelu departs her military-ruled country for the United States, she is forced to struggle with what it means to be black. This is due to the fact that, she never thought about being black, in Nigeria, but once she comes in America, she realizes that she is black. That is why Adichie (2017: 290) puts: "I did not think of myself as black and I only became black when I came in America." It means that black people become aware of their blackness out of their home countries, but in areas pertaining to white people.

Another case of racial decimation is experienced by Bartholomew when he asks for a loan to start a business. Unfortunately, moved by racial considerations, bank authorities reply negatively under the pretext that his credit is low enough to afford the needed loan. A Situation that he latercomplains about because a white man whose credit is critically low but has been granted a loan, as the narrator epitomizes: "He wants to start a business but they won't give him a loan and he says he will sue them for discrimination because his credit is not bad and he found out a man who goes to our church got a loan with much worse credit." (p.217)

Also worth knowing about racism is when Ifemelu is in tears after reading a post about Obama who is painted as a monkey, and is not allowed to be president: "How can a monkey be president? Somebody do us a favour and put a bullet in this guy. Send him back to the African jungle. A Black man will never be in the white house, dude, it's called the white house for a reason." (pp.353-354)

Here, the sentence "Send him back to the African jungle. A Black man will never be in the white house..." obviously evidences the White man's superiority complex over the Blacks who they purportedly reduce into infra-humanity.

Apart from America, racism is also evident in Europe and particularly in England with regard to Emenike and Obinze. Actually, these two African new comers experience racism when they go somewhere relax and take some beer. Unfortunately, the waitress is not eager to serve them, she even does not seem to care about them just because of their skin colour, as Emenikeremorses: "She is ignoring me. Did you notice how rude she was earlier? These Eastern Europeans just don't like serving black people." (p. 265) Emenike is also victim of racial discrimination when, standing on Upper Street to hail a taxi, but the driver simply avoids him and takes two white women after it passing him by: "From afar the cab light was on but as the cab approached him, the light went off, and he assumed the driver was not on duty. After the cab passed him by, he looked back idly and saw that the cab light was back on and that, a little way up the street, it stopped for two white women." (p. 275)

Similarly, racism is also an important issue namely in We Need New Names with regard to the protagonist, Darling, who is not a race blogger, but has, to some extent, experienced racism. In effect, Darling is also discriminated when she begins school in America. She is teased because of everything in her and is about to lose temper for she does not know what to do, as she confesses:

When I first arrived at Washington I just wanted to die. The other kids teased me about my name, my accent, my hair, the way I talked or said things, the way I dressed, the way I laughed. When you are being teased about something, at first you try to fix it so the teasing can stop but then those crazy kids teased me about everything, even the things I couldn't change, and it kept going and going so that in the end I just felt wrong in my skin, in my body, in my clothes, in my language, in my head, everything. (We Need New Names, p.165) 
Furthermore, migrants have some difficulties to adapt themselves to the new societies. According to H.M., Abrams (1985:11), 'adaptation' is "the adjustment to environmental conditions. The process or state of changing to fit a new environment or different conditions, or the resulting change."Indeed, when people enter a new culture, they always have some difficulties to adapt themselves, because they may have differences between what they have in mind while leaving and the reality on the host grounds. As it is easier said than done, they are disappointed once in the West. Indeed, people who flee their homeland for countries have to deal with some adjustments. Unfortunately, there is, most of the time a huge sense of disillusion in them.

In Americanah, for example, while leaving Nigeria for the United States, Ifemelu, thinks of America as a big country where everything glitters. But on her arrival and welcoming in Aunty Uju's house, she is flabbergasted to see herself sleep on the floor, as even Dike can feel:

How come she has to sleep on the floor, Mom? We can all fit in, as though he could sense how Ifemelu felt. There was nothing wrong with the arrangement-she had, after all, slept on mats when she visited her grandmother in the village - but this was America at last, glorious America at last, and she had not expected to bed on the floor. (Americanah, pp. 105-106)

Obviously, it is not easy for Ifemelu to adjust to her new place. For instance, when it comes to get ready for an interview, Ifemelu is told that she shall not wear braids, for, not to look unprofessional. Ifemelu is astonished about that view point because she wants to have braids and then wonders whether doctors does also the same. But Aunty Uju advises her to make some adjustments to achieve success: "You are in a country that is not your own. You do what you have to do if you want to succeed." (p.119) Indeedbeing no longer in her homeland, Ifemelu has to accept certain things because she has no choice when she shares the same house with girls she does not know at all, by sharing having a tiny room with a fridge and a toilet. That is why the authoress writes: "she was standing at the periphery of her own life, sharing a fridge and a toilet, a shallow intimacy, with people she did not know at all." (p.128)

It is important to note that sometimes people become alienated in their need to get familiar with the American culture. Indeed they try to abandon their own culture in order to adapt themselves with the American one. It is in this perspective that Aunty Uju dislikes and admonishes her son Dike for speaking Ibo, under the pretext that two languages will confuse him. A form of alienation, a loss of their culture and identity that let Ifemelu dazed: "What are you talking about, Aunty? We spoke two languages growing up."(p.109) And Aunty Uju harshly replies: "This is America, it's different." (p.109) Aunty Uju's admonition tells more about her desire to see her Ibo son quickly acquire the American social standards. Thus, she urges him to forge a new identity as many other immigrants do in their search for their recognition.

As can be seen, under the pressure of the American society, migrants exchange their linguistic identity and need to feign an American accent with the intention of impressing the white men about their language proficiency. This is the case of Aunty Uju switches from her usual accent for newly acquired American one that Ifemelu describes as "...nasal, sliding accent she put on when she spoke to white Americans, in the presence of white Americans, in the hearing of white Americans. Pooh-reet-back and with the accent emerged a new persona, apologetic and self-debasing" (p.108). Similarly,Ifemelu's classmate, Bisiwho just after shortly visiting America for vacation, changes her Nigerian accent, and pretends not to understand the Yoruba language.

However, alteration of migrants' self-identity is also one of the depriving consequences of clandestine migration. In fact, the host environment is too challenging that immigrants are induced to relinquish cultural patrimony and even exchange their names to avoid stereotypic narratives around African names which are often mispronounced by white folks. As an illustration, in Americanah, Ifemelu's and Obinze's identity is grossly fractured in America and England in their search for job. In effect, Ifemelu is induced to exchange illegally his name for 'Ngozi Okonkwo' in indoor to find a job as a babysitter/ "relaxer" to a tennis coach in America.

In the same perspective, Obinze is forced to work under the assumed identity of 'Vincent' (p.250) with a fake National Insurance Number. Hence, takes up a new identity to enable him get a job as a warehouse boy in London. 
This kind of alienation reminds of Chika Unigwe's On Black Sisters' Street where Sisi and Alek, two female characters who willingly accept to get alienated in exchange for their integration. Chisom, for instance is depicted to have "already decided to change her name, to adopt a name that she would wear in her new life. Sisi. Sister in Shona" (p.44). For she thinks, Sisi sounds so attractive to secure her job of a prostitute in Belgium.

Another aspect of cultural alienation is seen in the authoresses' use of body looking, and especially, hair exchange metaphor. Ifemelu and other female African immigrants are obliged to change their natural hair because the natural texture of Black female hair is not welcomed by white Americans who, moved by racial considerations, regard them as primitive. It is also important to note that Ifemelu is facing a new concept of "kinky" hair. This is the case of Aunty Uju who has to pass her medical exams and, immediately needs to take out her braids and relax her hair for her interviews because Americans think that braids are unprofessional. As matter of fact, "Some black women, AB and $N A B$, would rather run naked in the street than come out in public with their natural hair. Because, you see, it's not professional, sophisticated, whatever, it's just not damn normal." (Americanah, p.297)

This idea of taking out braids and relax hair also haunts Dele who dissuades Sisi newly arrived in Belgium not braiding her hair but to buy quality hair extensions in order to "look like oyibowoman", a ready-yield one for 'customers'. (On Black Sisters' Street, p.31)

From these surmises, Ifemelu, Obinze and other African immigrants are disillusioned for theyrealize that the America they have been looking for was never real at all - it only exists in media and hearsay. They hope that leaving Nigeria by all means for America would usher in robust employment opportunities in the labour market. For they have always heard of American certificate as a key to better jobs. Unfortunately, they are totally disenchanted to find that Dike seems behind where he would be if he were schooling at home. Dashed hope! They then never see their dreams of migrating to Western 'Eldorados' come true, rather America shatters their hopes and destinies.

Ifemelu's and Obinze's disillusionment reminds that of Darling who wonders if she really is in America, the 'eldorado' she has been longing for while at home. Accordingly, C. Concilia (2018: 43) asserts: "[...] migration is like falling from the sky, a sort of new birth that erases the past and provides only the future."Darling's disenchantment starts with the hostile weather conditions she welcomes in. In fact, during her first days in Detroit Michigan, there is no sun and everything is covered with snow. Moreover, she cannot go out and complains about it:

With all this snow, with the sun not there, with the cold and dreariness, this place doesn't look like my America, doesn't even look real. It's like we are in a terrible story, like we are in the crazy parts of the Bible, there where God is punishing people for their sins and is making them miserable with all the weather. (We Need New Names, pp. 150-151)

Darling is simply flabbergasted by the unexpected reality she finds on the new ground. She cannot help imagining that the America she has longed for is refusing to integrate her and even the severe weather conditions seem not favour her: "As for coldness, I have never seen it like this, I mean, coldness that makes like it wants to kill you, like it's telling you, with its snow, that you should go back to where you came from." (We Need New Names, p. 148)

In effect, Darling dreamt for America as a "country-country", that is to say a real country just like Budapest, the wealthier city she knew at home with all life amenities. Paradoxically, she is disillusioned to see that Aunt Fostalina's house which welcomes her is not made of planks, not bricks. Furthermore, there are some gunshots outside, so that she has to stay inside. When she talks to her friends back home, on the phone, she hides these things and many other ones, as evidenced in the following passage:

That the house we lived in wasn't even like the ones we'd seen on TV when we were little, how it wasn't made of bricks but planks, a house made of planks in America, and how when it rained those planks got mold and smelled. I didn't tell them how in the summer nights there sometimes was the bang-bang-bang of gunshots in the neighbourhood and I had to stay indoors, afraid to go out, and how one time a woman a few houses from ours drowned her children in a bathtub, all four of them, how there were poor people who lived on the streets, 
holding up signs to beg for money. I left out these things and a lot more, because they embarrassed me, because they made America not feel like My America, the one I had always dreamed of back in Paradise. (We Need New Names, pp. 187-188)

From this quotation, one easily infers how difficult and alienating it is for the immigrants to be integrated into the American society. For, they somehow lose their identities, their culture, speak like Americans if there is any hope be considered as worthy Americans. This is reason why Darling, for instance has a list of American words that she keeps as a talisman and uses them in order to prove her proficiency in the American English. Hence, she and other immigrants are ashamed to speak their own languages, or simply cannot, because aware they are that America is not home for them:

Because we were not in our country, we could not use our own languages, and so when we spoke our voices came out bruised. When we talked, our tongues thrashed madly in our mouths, staggered like drunken men. Because we were not using our languages we said things we did not mean; what we really wanted to say remained folded inside, trapped. In America we did not always have the words. It was only when we were by ourselves that we spoke in our real voices. When we were alone we summoned the horses of our languages and mounted their backs and galloped past skyscrapers. Always, we were reluctant to come back down. (We Need New Names, p. 240)

Because they lack papers and are considered as illegal residents in their new lands, migrants resort to sham marriages in order to earn citizenship and get menial jobs. Some, for instance, look for a brides and suitors who have papers and convince them to have a sham marriage and divorce once they become legal residents. In We Need New Names, Bulawayo provides illustrations with regard to Dumi who, after failing to get legal resident documents, he decides to marry a woman he is not in love with. Actually, Dumi marries a white woman whose monstrous looking astonishes all their guests. The Bride was too fat and ugly that even some of African fellows, who attend Dumi'swedding ceremony, especially Darling Aunt Fostalina tease to ridicule their couple:

It was fatness that did not interfere with the body; a neck was still a neck, a stomach a stomach, an arm an arm, a buttock a buttock. But this American fatness takes it to a whole' nother level: the body is turned into something else-the neck becomes a thigh, the stomach becomes an anthill, an arm a thing, a buttock a I don't even what. The tall husband, Dumi is sitting beside the bride in his white suit. He has this smile that never goes away, his tinted dreadlock reach his shoulders, and his body looks like a stick in comparison to his wife's. I look at this carved smile and ask myself what he's smiling for because I don't see why anyone would be smiling with a bride like that... I look at Aunt Fostalina and she is all smiles looking at the couple, and I know the reason she is so happy is that Dumi's bride is fat and ugly. (p.171)

Similarly, Adichie tackles this issue of with two emblematic cases: Obinze's and Aisha's sham marriages. Indeed, when Obinze arrives in England for the first time, he is received by Nicholas, his cousin who advises him to get a National Insurance number which can help him not only getting a job synonymous of earning enough money in order to get married later to a woman from the European Union.

If you come to England with a visa that doesn't allow you to work, Nicholas told him, the first thing to look for is not food or water, it is an NI number so you can work. Take all the jobs you can. Spend nothing. Marry an EU citizen and get your papers. Then your life can begin. (Americanah, p. 238)

The rationale behind Nicholas advises is to help Obinze regularize his immigration situation and start a secure life in the host country. Obinze willingly accepts and is helped by some Angolans who arrange for him a sham marriage with Cleotilde in order to become a legal resident in England. Unfortunately, he does not succeed, because he is caught by immigrant officers and two policemen, just while they are about to get married. In fact, the immigrant officer brings a copy of Obinze's passport as a proof, in order to remind him that his visa has expired, as he warns: "Your visa is expired and you are not allowed to be present in the UK." (p.279) Subsequently, Obinze is arrested and deported from England without any human consideration. 
As for Aisha, a Senegalese immigrant lacking legal resident papers in America, she is even prevented to go back home when she loses her father. She then plans a sham marriage with Chijioke, one of her lovers, a way to get papers and go back home when her mother will die: "Last year, My father die and I don't go, because of papers. But maybe, if Chijioke marry me, when my mother die, I can go. She is sick now." (Americanah, p. 365)

As far as menial jobs are concerned, it is important to note that they are these jobs people neglect or refuse to do for they are, to some extent, dirty and degrading. The adjective 'Menial' is always associated to those jobs "relating to or involving work that requires little skill or training, are not interesting, and confers low status on somebody because often boring and badly paid" (A.S. Hornby. 2005, p.920) In the novels under consideration, heroines are saddled with the rigor of menial jobs as the only opportunity offered to them in the host lands. Hence, when he arrives for the first inEngland, in spite of Obinze's excellent grades and upbringing, the first job opportunity Obinze has is that of cleaning toilets. A 'shameful' job that you could not willingly accept to do at home. One evening, for instance, while cleaning toilets, Obinze is surprised to come across a mound of shit on the toilet lid. $\mathrm{He}$ is so shocked that he stops with the job, as he narrator evidences:

He was shocked, one evening, to walk into a stall and discover a mound of shit on the toilet lid, solid, tapering, centered as though it had been carefully arranged and the exact spot had been measured.it looked like a puppy curled on a mat. [...] Obinze stared at that mound of shit for a long time, feeling smaller and smaller as he did so, until it became a personal affront, a punch on his jaw. And all for three quid an hour. He took off his gloves, placed them next to the mound of shit, and left the building. (Americanah, pp. 236-237)

Unfortunately, it is not easy for Obinze to find a well-paid job as an illegal immigrant, he, with the help lloba, manages to secure a temporary visa to the UK where he is forced to work under the assumed identity of "Vincent" (250) with a fake National Insurance Number. Obinze takes up a new identity to enable him get a job, but just for a very short period, for the deal will not last by his disloyalty. Indeed, cconsumed by immigrations worries, Obinze agrees with Vincent to give him the percentage he wants. He needs money to finish with his sham marriage. But one day, Vincent calls Obinze and tells him that he needs a raise. Obinze ignores him, because he wants to save more money and Vincent simply reports him to Roy, his boss, who finally is unmasks dismisses him, as evidenced in the following passage: "Somebody called yesterday. Said you're not who you say you are, that you're illegal and working with a Brit's name. [...] Why don't you just bring in your passport tomorrow and we'll clear it up, all right?' (p.261)

As far as Ifemelu is concerned, she cannot work in America, because she only has a student visa. But as she has to afford some expenses by herself, Aunty Uju helps her by asking Ngozi Okonkwo to let her Social Security card to Ifemelu, because she is going back home for a while. The following passage is very eloquent:

You can't work with your student visa, and work-study is rubbish, it pays nothing, and you have to be able to cover your rent and the balance of your tuition. Me, you can see I am working three jobs and yet it's not easy. I talked to one of my friends, I don't know if you remember Ngozi Okonkwo? She is now an American citizen and she has gone back to Nigeria for a while, to start a business. I begged her and she agreed to let you work with her Social Security card. (Americanah, p. 106)

But the thing is, it is not evident to use another person's name, because one may forgets it. That is why Ifemelu has to keep the name in mind, because if she forgets, even your co-workers can report you. Aunty Uju tells Ifemelu that she just has to remember her new name, because one of Aunty Uju's friend has been reported to immigration, as she has forgotten her so-called name: "Just make sure you always remember your new name. I have a friend who forgot and one of her co-workers called her and called her and she was blank. Then they became suspicious about her and reported her to immigration." (Americanah, p. 121) Unfortunately, after several unsuccessful attempts, she cannot find a good job. Hence, when she becomes late for rent, her roommates begin to despise her be responsible for their rental problems. To challenge this affront, Ifemelu finally calls the tennis coach, for even dirty jobs, just a way to earn few dollars. What is degrading is in this deal is that Ifemelu is expected to go to the coach's place and unleash his sexual pressure through masturbation. After this 
alienation session, Ifemelu becomes very ashamed and bitterly regrets her adventure to America, as the narrator better puts it:

She did not want to be here, did not want his active finger between her legs, did not want his sigh-moans in her hear, and yet she felt her body rousing to a sickening wetness. [...] He had not forced her. She had come here on her own. She had lain on his bed, and when he placed her hand between his legs, she had curled and moved her fingers. Now, even after she had washed her hands, holding the crisps, slender hundred-dollar bill he had given her, her fingers still felt sticky; they no longer belonged to her. (Americanah, p. 154)

Actually, Ifemelu has lost her dignity, and is then Ifemelu near to commit a suicide as the only way out from this hazardous life, as the narrators keeps on: "She knew there was no point in being here, in being alive, but she had no energy to think concretely of how she could kill herself." (p. 156)

Like many immigrants in Western countries, Darling, in We Need New Names, is also saddled with the rigours of menial jobs, described as backbreaking jobs or low-paying ones:

And the jobs we worked, Jesus-Jesus, the jobs we worked. Low-paying jobs. Backbreaking jobs. Jobs that gnawed at the bones of our dignity, devoured the meat, tongued the marrow. We took scalding irons and ironed our pride flat. We cleaned toilets. We picked tobacco and fruit under the boiling sun until we hung our tongues and panted like lost hounds. We butchered animals, slit throats, drained blood. (WeNeedNewNames, p. 244)

As can be seen, these jobs are not only degrading but they sometime expose her to evident health hazard, as she keeps on complaining:

When I'm not cleaning the toilets or bagging groceries, I'm bent over a big cart like this, sorting out bottles and cans with names like Faygo, Pepsi, Dr Pepper, 7-Up, root beer, Miller, Budweiser, and Heineken. [...] The beer bottles are the worst. They will come with all sorts of nasty things. Bloodstains. Pieces of trash. Cigarette stubs drowning in stale beer the colour of urine, and one time, a used condom. When I started working here, back in tenth grade, I used to vomit on every shift. (pp. 251, 253)

Darling's psychological torture at work even continues especially when Aunt Fostalina asks her to work for Eliot. Unluckily, Darling dislikes cleaning other persons' houses, and is about to reject the offer, as she contends: "When I'm not working at the store, I have to come here, even though I don't like the idea of cleaning somebody's house, of picking up after someone else, because in my head this is not what I came to America for." (p.263)

Besides, illegal immigrants permanently live in fear to be asked for their resident papers. Thus, in the supposedly land of opportunities, these clandestine residents sometimes hide their real names and use other persons' names to go out seeking even for menial jobs reserved to them. A parasitic life as Darling epitomizes it:

Because we were illegal and afraid to be discovered we mostly kept to ourselves, stuck to our kind and shied away from those who were not like us. We did not know what they would think of us, what they would do about us we did not want their wrath, we did not want their curiosity, we did not want any attention. We did not meet stares and we avoided gazes. We hid our real names, gave false ones when asked. [...] When they talked about employers checking on workers, our hearts sank. We recalled the tatters of our country left behind, barely held together by American dollars, by monies from other countries, and our blood went cold. And when at work they asked for our papers, we scurried like startled hens and flocked to unwanted jobs, where we met the others. (We Need New Names, pp. 142-143)

The above quotations show that clandestine migrants live like invisible persons, simply because they are afraid to be caught and for this reason they rush towards poorly paid jobs. The phrase "our blood went cold" and the sentences such as "we mostly kept to ourselves, stuck to our kind and shied away from those who were not like us" or "we scurried like startled hens and flocked to unwanted jobs" clearly indicate that black people have lost their own identity, and are reduced into infra-humanity. An aspects that Maria Duckham (2017: 43) documents when she writes: 
The fear of being caught pushes people further into hiding and forces them to accept jobs which are poorly paid, potentially illegal and often unsafe. In terms of identity it forces the individuals concerned to sever themselves from their roots and negate who they are. This equates to psychological suicide because in order to survive they have to pretend to be someone else and every decision they make to create their new identity is to the detriment of their true self.

Life in America is very challenging that when her mother calls and asks for money, Darling does not dare pass on the message to Aunt Fostalina whom she pities for accepting menial jobs just to earn meet the family amenities, as she confesses: "I had meant to give Aunt Fostalina the message, but then when she came in from her second job later that night, her body looking like a sack, and threw herself on the La-Z-Boy and let out a tired sigh, I just didn't have the courage." (We Need New Names, pp. 205)

After a given period in their new land and, due to many intricacies faced there, African immigrants suffer homesickness. According to The New International Webster's Comprehensive Dictionary of the English Language (2004:604), 'homesickness' caries connotations of "being nostalgic, and suffering in mind or body through longing for home and family while absent from them."Put in another way, it is referred to as the attitude of being sad because we are away from home and we miss our family and friends. Indeed, when one travels abroad, due to what one experiences in the host land, people may become nostalgic. It is in this connection that, after a long stay in America, though she has a blog, a fellowship at Princeton and she is in relationship with Blaine, Ifemelu is not at ease. She becomes homesick and feels much like trying to know more about Nigeria, and also know about those who have moved back home:

$[\ldots]$ and yet there was cement in her soul. It had been there for a while, an early morning disease of fatigue, a bleakness and borderlessness. It brought with it amorphous longings, shapeless desires, brief imagery glints of other lives she could be living, that over the months melded into a piercing homesickness. She scoured Nigerian websites, Nigerian profiles on Facebook, Nigerian blogs, and each click brought yet another story of a young person who had recently moved back home, clothed in American or British degrees, to start an investment company, a music production business, a fashion label, a magazine, a fastfood franchise. (Americanah, p. 6)

It goes out from this quotation that Ifemelu becomes homesick despite her success in her blog and still feels unaccomplished, as M. Peed (2013:15) writes: "The blog gains popularity. Even so, amorphous longings, shapeless desires resurface, calcifying into an intense homesickness." As she becomes homesick, Ifemelu begins thinking about going back home and tells Ranyinudo about her intention. To hear Aisha saying good things about Nigeria makes her think much about home. She is even looking for signs, positive signs, as the narrator puts it: "This was what she had become, a seeker of signs, Nigerian films were good, therefore her move back home would be good." (p. 14)

Similarly, in We Need New Names, due to many life complexities they endure in the host lands, African immigrants become nostalgic of their home countries, as they can help wailing again and again for their blessed Africa. In Chapter sixteen entitled 'How they Lived', Bulawayo epitomizes these immigrants' homesickness through the narrator's mouth:

When they asked us where we were from, we exchanged glances and smiled with the shyness of child brides. They said, Africa? We noddle yes. What part of Africa ?We smiled. $[\ldots]$ We exchanged glances again and water in our eye broke. Our smiles melted like dying shadows and wept; we wept for our blessed, wretched country. We wept and wept and they pitied us and said; It's okay- it's okay, you are in America now, and still we wept and wept and wept and [...] we wept still, wept like widows, wept like orphans.(We Need New Names, pp. 237-238)

Here, sentences such as "Our smiles melted like dying shadows and wept; we wept for our blessed, wretched country" and the phrase "and still we wept and wept and wept and [...] we wept still, wept like widows, wept like orphans" dramatize immigrants in turmoil, for they realize that they have lost the quintessence of their life. Darling is the embodiment of this homesickness, for she is nostalgic of 
her homeland, her family and her friends. Indeed, when she arrives in America, Darling faces snow which prevents her from going out. She is just locked in the house, doing nothing, then she begins thinking about home and her friends. She thinks about being out with her friends and live life:

If I were at home I know I would not be standing around because something called snow was preventing me from going outside to live life. Maybe me and Sbho and Bastard and Chipo and Godknows and Stina would be out in Budapest, stealing guavas. Or we would be playing Find bin Laden or country-game or Andy-over. (We Need New Names, p. 153)

At the beginning, Darling writes to her friends to keep in touch with them as promised when still at home. Though she loses contact with them after a certain period, but she does not forget them as such. For, when she receives the guavas they sent, Darling realises her homesickness, and pathetically asserts:

[...] before I knew it, I'd lost touch. But it didn't mean I'd forgotten about them; I missed them, missed them very much, and there were these times when I'd be doing something and get this terrible feeling of guilt for not keeping in touch. I also missed Budapest, missed Fambeki, missed Paradise, missed Mother and Mother of Bones and Mother Love, all those people, even Prophet Revelations BitchingtonMborro, with his craziness, I missed them all. And when I got the guavas the gang sent with Messenger, these years later, it felt good knowing they remembered me as well. (p. 188

From the sentence "...there were these times when I'd be doing something and get this terrible feeling of guilt for not keeping in touch" One easily infers Darling's homesickness for Paradise as it still impacts on her psyche. Thus, she is haunted by the desire of going back home to reconnect with everybody and everything, as she endeavours inducing Aunt Fostalina about her "psychological healing project'. A return to the sources that Aunt Fostalina does not share because she dissuades Darling eating again guavas, the metaphor of psychological reconnection to her childhood memoires in Paradise. Aunt Fostalina first reacts, telling her that it will constipate her. But there is a real pleasure in Darling to eat guava again, sending her back home, as she confesses:

Dahedhoped!, for Darling has her mind already made up. Returning home is the only way to heal from the psychosocial trauma caused by the 'effects of mobility': "I just keep chewing; how can she understand that each time I take a bite, I leave the house, Kalamazoo, and Michigan, leave the country altogether and find myself back in my Paradise, in Budapest?" (p.186)

Furthermore, Darling becomes sad when she eats the last of the guavas as she knows that it will be difficult for her to eat guavas again, guavas from home: "I just ate the last of the guavas and already I have this sadness thinking about the length of time, maybe years, before I will taste guava again." (p.193) This attitude shows how much Darling is still attached to her homeland and except the fact that she can eat as much food as she wants, it cannot satisfy the hunger she has for her motherland, as she asserts: "There are times, though, that no matter how much food I eat, I find the food does nothing for me, like I am hungry for my country and nothing is going to fix that." (p.153)

As the story unfolds, one figures out that voyage back home proves a risky project for it does not really fill Darling's expectations, as she wonders:

... I go back my country, but then I don't really know because will Paradise be there when I return? Will Mother of Bones be there when I return? Will Bastards and Godknows and Sbho and Stinanad Chipo and all my friends be there when I return? Will the guava trees be there when I return ? Will Paradise, will everything, be the same when I return ? (p.160)

In effect, like for many immigrants, Darling's returning back results in a mere disenchantment for not only has her contact with an alien culture dehumanized her, but in Paradise things are now irreversibly upside-down, as Stina and MukomaSharlie attempt to appease Darling from her endless and traumatic questions:

A country is a Coca-Cola bottle that can smash on the floor. And disappoint you? When a bottle smashes, you cannot put it back together. [...] You are the most unfortunate children this broken bottle has ever seen. When it was still a country you would all be at school doing some serious learning so you would all grow up and be somebodies, but here you are, 
squatting in the bush, guavas ripping your anuses. [...] Leaving your country is like dying, and when you come back you are like a ghost returning to earth, roaming around with missing gaze in your eyes.(p.160)

From this quotation, one surmises that candidates to return migration are not only disillusioned but grossly uprooted since they are longer recognized by their own tribesmen for they are like " $a$ ghost returning to earth, roaming around with missing gaze in your eyes." Yet, Darling's father just coming back home from South Africa buttresses well the metaphor of "Leaving your country is like dying", as the Heroine almost mourns on her dying father:

Father comes home after many years of forgetting us, of not sending us money, of not loving us, not visiting us, not anything us, and parks in shack, unable to move, unable to talk properly, unable to anything, vomiting and vomiting, Jesus, just vomiting and defecating on himself, and it smelling like something dead in there, dead in rotting, his body a black, terrible sick. (p.89)

As can be seen, the failure of Darling's father in South Africa is far from being trivial. He is takenas the microcosm of all these African immigrants who, moved by some perceived adverse socio-political and economic conditions, seem to have escaped home for the 'Eldorado', but they are plunged into the pluralistic and confusing world with indeterminate parameters.

\section{Authoresses' CRITICISM Of MigRation AS IdeOlogiCAl WEAPON}

Adichie's and Bulawayo's contribution to the burning issue of illegal migration plaguing most countries in Africaholds in two ideological lines: migrating is an option but should not be a necessity, for "everywhere where people live, there is suffering". (We Need New Names, p.285) This dissuasive ideology reads quite clear through Shipo's mouth, blaming Darling for having fled Africa:

Just tell me one thing. What are you doing not in your country right now? Why did you run off to America? Why did you just leave? If it's your country, you have to fight for it no matter what, to make it right. Tell me, do you abandon your house because it's burning or do you find water to put out the fire? And if you leave it burning, do you expect the flames to turn into water and put themselves out? You left it, Darling my dear, you left the house burning and you have the guts to tell me, in that stupid accent that you were not even born with, that doesn't even suit you, that this is your country? (We Need New Names, p.286)

In effect, both Authoresses appeal the African youth to 'Resilience' is this "ability of government to identify, assess, and respond to a potentially disruptive situation in order to prevent it from becoming a crisis". (p. 1242) Henceforth, since, the evils plaguing most of African countries have already well identified, rather than fleeing the house because it is burning, African brave youths are urged to stay and react in order to face the potential challenges. Rather feeling sorry for their own fate, they need to be more imaginative and creative in order to grasp the opportunities that the African continent offers, especially in terms of natural resources.

Furthermore, Since the West offers African immigrants little of their varied expectations, why keeping on living in servitude and anonymity. Why not returning home to live a stable and fulfilling life? Adichie and Bulawayo level serious reproach against these African immigrants who keep on enjoying a status of clandestinity and infra-humanity in hostile Western environments, as the heroine of We Need New Names is full of remorse: "We did not go back home to visit because we did not have the papers for our return, and so we just stayed, knowing that if we went we would not be able to reenter America. We stayed, like prisoners, only we chose to be prisoners and we loved our prison; it was not a bad prison."(We Need New Names, pp. 246-247)

Are they still persons when they suffer the pressure of a society that hinders their individual goals and the development of their selfhood. Their dream is so frustrated that they suffered homesickness, considering themselves like prisoners in the host lands for they are even denied the right to back home because of the lacking of regular papers. Darling's confession "we loved our prison; it was not a bad prison", is ironical for no one enjoys captivity. A degraded mentality that they handle down to their progeny, whoever, totally uprooted, will perpetuate, not willing to get out of this prison, as Darling furthers: 


\begin{abstract}
When our own children were born $[\ldots]$ we did not want to tell them we still had no paper. And when they grew restless and cursed America for being the greedy monster that swallowed their children, swallowed their sons and daughters of other lands and refused to spit them out, we said, We are coming very soon, we are coming next year. And next year came we said, Next. When next year came we said, Next year for sure. And when year for sure came we said, next year for real. And when next year for real we said, We are coming, you'll see, just wait. And our waited and they saw, saw that we did not come. [...]When we died [...] We will leave for the land of the dead naked, without the things we need to enter the castle of our ancestors. Because we will not be proper, the spirits will not come running to meet us, and so we will wait and wait and wait- forever waiting in the air like flags of unsung countries. (We Need New Names, pp. 247, 248, 250)
\end{abstract}

All things considered, the illustration of Adichie and Bulawayo's ideology, respectively in Americanah and in We Need New Names is perceptible through the lampooning intricacies of migration, especially exposing the psychological trauma of their transnational characters.

\title{
5. CONCLUSION
}

As it is highlighted by the topic of this study, this research has dealt with analysis of Americanah by and We Need New Names by two famous female authors, the Nigerian Chimamanda Ngozi Adichie and the Zimbabwean NoViolet Bulawayo. The criticism of these novels analyzed qualifies them satirical, because they both point a finger of issues of migration as it continues to plague most of African countries. Both writers Adichie and Bulawayo consider and position art as an ideological weapon or an antidote to the illusion of migration, and warn the human society due to the consequences that result in it. In fact, what happen in both narratives are also taking place in our societies across the globe. Therefore, this work has contextualized the content of these novels in order to clarify the impact of devastating phenomenon for the sake of dissuading prospective candidates to flee Africa and embark for the gloomy and risky path of clandestine immigration. As a final assessment, these magnum opuses, Americanah and We Need New Names, rank among the recent literary texts focusing on the social contexts which prompt the immigrants to flee African, on the experience of migration itself, on the mixed reception which they may receive in Western 'Eldorado', on experiences of racism and hostility, and on the sense of rootlessness and the search for identity which finally leads to a mere disenchantment. The immigrants' portrayed feel and suffer the pressure of a society that hinders their individual goals and the development of their selfhood. They seem to have escaped home to the West as a result of some perceived adverse socio-political and economic conditions but they are plunged into the pluralistic and confusing world of race varieties with indeterminate parameters.

\section{REFERENCES}

[1] Aboulela, Leila. (2018). Elsewhere, Home, Telegram Books.

[2] Adichie, Chimamanda Ngozi. (2003). Purple Hibiscus. Chapel Hill: Algonquin Books.

[3] Adichie, Chimamanda Ngozi. (2006). Half of a Yellow Sun. London: Fourth Estate.

[4] Adichie, Chimamanda Ngozi. (2013). Americanah. Lagos: Farafina. Print.

[5] Agyekum, Kofi. (2013). Introduction to Literature. $3^{\text {rd }}$ Edition. Accra: Adwinsa Publications Ltd.

[6] A.S. Hornby. (2005). Oxford Advanced Learner's Dictionary of Current English. $7^{\text {th }}$ ed. London: Oxford.

[7] Bulawayo, NoViolet. (2014). We Need New Names. London: Vintage.

[8] Concilia, Carmen. (2018). "We Need New Names by NoViolet Bulawayo. Paradigms of Migration: The Flight and the Fall”.Le Simplegadi. Vol. XVI-8. DOI: 10.17456/SIMPLE-94.

[9] Declercq, Elien. (2011). «Écriture migrante », « littérature (im)migrante », « migration literature »:

[10] réflexions sur un concept aux contours imprécis".Revue de littérature comparée /3 (n³39). pages 301 à 310.

[11] Diakhate, Babacar. (2019). "Politics, Utopia and Disillusionment in Noviolet Bulawayo's We Need

[12] New Names". BIRCI-Journal, Humanities and Social Sciences. Volume 2, n ${ }^{\circ}$. DOI: https://doi.org/10. 33258/birci.v2i1.146.

[13] Dustmann, C. and Weiss, Y. (2007). "Return Migration: Theory and Empirical Evidence from the

[14] UK.”.British Journal of Industrial Relations. Vol. 45, No. 2. pp. 236-256. 
Art as an Antidote to Clandestine Migration: a study of Chimamanda Ngozi Adichie's Americanah and NoViolet Bulawayo's We Need New Names

[15] Emecheta, Buchi. (1974). Second-Class Citizens. London: Allison \& Busby.

[16] H.M., Abrams. (1985). A Glossary of Literary Terms. London: Holt, Rinehard and Winston.

[17] Jay, Paul. Global Matters: The Transnational Turn in Literary Studies. USA: Cornell UP. 2010. Print.

[18] Juompan-Yakan, Clarisse. (2020). “Nigeria’s Chimamanda Ngozi Adichie Talkscolonialism,

[19] politicsand pop culture". The Africa Report. https://www.theafricareport.com/27060/nigerias-chimamandangozi-adichie-talks-colonialism-politics-and-pop-culture/.

[20] Kabore, André. (2016). “Migration in African literature: a Case Study of Adichie's works”. Revue

[21] du CAMES Littérature, langues et linguistique Numéro 4, 1er Semestre.

[22] Katie, Petersen. (26/03/2020).Migrant and Migration Literature. Germany, www.yorku.ca.

[23] Pearson, Laura. (2013). The Chicago Tribune: Review: Americanah by Chimamanda Ngozi Adichie.

[24] Peed, Mike. (2013). "Realities of Race: Americanah, by Chimamanda Ngozi Adichie," New York Times. $7^{\text {th }}$ June.

[25] Peschel, Sabine. (2015). "Zimbabwean author NoViolet Bulawayo: I like to write from the bone."

[26] DW made for minds, http://www.dw.com/en/zimbabwean-author-noviolet-bulawayo-i-like-towrite-fromthe-bone/a-18572543.

[27] Saraki, Bukola. (2018). "Senate Roundtable on Migration and Human Trafficking." African Independent Television, Feb. 26.

[28] Smith David. (September 4, 2013). "NoViolet Bulawayo tells of heartbreak of homecoming in

[29] Mugabe's Zimbabwe". The Guardian.amp.theguardian.com.

[30] Steger, Jason. (August 1, 2014). "NoViolet Bulawayo-a cry for home". https://www.smh.com.au/ entertainment/books/noviolet-bulawayo--a-cry-for-home-20140728-zxlul.html.

[31] Taylor, Jack. (2019). “Language, Race and Identity in Adichie's Americanah and Bulawayo's We

[32] Need New Names". Research in African Literatures. Vol. 50, $\mathrm{n}^{\circ} 2$. Special Issue: The Performance of PanAfricanism.pp.68-85.Indiana University Press. https://doi.org/10.2979/reseafrilite.50.2.06.

[33] The New International Webster's Comprehensive Dictionary of the English Language. Florida:

[34] Trident International Press, 2004.

[35] Unigwe, Chika. (2009). On Black Sisters' Street. London: Vintage Books Print.

[36] Woetzel, Damian. (2014). "Interview with Adichie Chimamanda Ngozi”. Youtube, uploaded by the Aspen Institute.

[37] “Zimbabwe's Operation Murambatsvina: The Tipping Point?” Crisis Group Africa Report. (17 August 2005) $\mathrm{N}^{\circ}$ 97. Pretoria/Brussels.

\section{AUTHOR'S BIOGRAPHY}

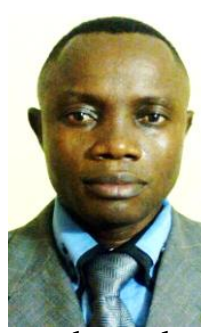

Dr. Alphonse Dorien MAKOSSO, a fulltime Senior Lecturer (CAMES) of African Anglophone Literature at Marien Ngouabi University (Republic of Congo). I defended a doctoral dissertation entitled: "Protest, Conflict and Aesthetics in Ngũgĩ WaThiong'o's Novels" in December 2015. My research focus is on fiction in general. I am a member of Groupe de Recherche en Sciences du Langage et Didactique des langues- Etudes linguistiques, littéraires et didactiques (GRESLA-DL).My devotion to African Anglophone Literature is shown by the publication of eight scientific papers. I teach under graduate and master students. I have a research project of publishing a book on 'Ngũgĩsm' ie. Ngũgĩ waThiong'o'sideological stances.

Citation: Alphonse Dorien Makosso. "Art as an Antidote to Clandestine Migration: a study of Chimamanda Ngozi Adichie's Americanah and no Violet Bulawayo's We Need New Names" International Journal of Humanities Social Sciences and Education (IJHSSE), vol 8, no. 9, 2021, pp. 39-56. doi: https://doi.org/10.20431/2349-0381.0809005.

Copyright: (c) 2021 Authors. This is an open-access article distributed under the terms of the Creative Commons Attribution License, which permits unrestricted use, distribution, and reproduction in any medium, provided the original author and source are credited. 